\title{
Making Informal Politics Work: A Case of Local-Direct Election In Bangka Selatan, Indonesia
}

\author{
AgamPrimadi', David Efendi', Husni Amriyanto 3 ,RifkiSanahdi ${ }^{4}$ \\ UniversitasMuhammadiyahYogyakrta, Indonesia \\ Email:agamprimadi@gmail.com ${ }^{1}$,defendi@umy.ac.id²,choenny@yahoo.com ${ }^{3}$,rifkisanadi12@gmail.com ${ }^{3}$
}

\begin{abstract}
The existence of informal actors like local strongman and the like is another consequent of localizing democracy in Indonesia nationwide. This research-based paper aims to analyze the existence of informal actors in influencing and shaping electoral process namely local election in Bangka Selatan, Sumatra, Indonesia. To acknowledge the local-informal actor in this case, researchers employ some theoretical frameworks like informal politics, elites, and Bourdieu's theory of capitals, in concerning the post-authoritarian state and transitional democracy in Indonesia which is signed by informal actors, process and also patronage model. It is obvious then, that money is not always a central actor within electoral process but another factor like informal networks is quite effective and significant ones. This finding will be very contributive to get better and factual understanding in seeing local politics dynamic in the contemporary democratic regime in Indonesia.
\end{abstract}

Keywords: Local Election, Decentralization, Democracy, Informal Politics, NGO

\section{INTRODUCTION}

There are fundamental changes in the electoral system in Indonesia after the reformation of 1998. Firstly. the electoral system was labeled as s pseudo-democratic during new order but now, much more democratic. Secondly, in the 2004 elections was held for legislative and the presidential election. This fundamental change has been affecting the system, structure, competition, and the behaviors of the institutions in elections.In addition, political changes have been seen, for example, through the first, process Post-New Order political liberalization which allows political actors to relish a free and open political situation in articulating and organizing interests through political parties and gaining political support. Second, democratic institutional reforms encourage the political actors involved to be relatively large, diverse and have a higher level of density than the New Order era. In that era, the actors involved in the public policy-making process were extremely limited and ranged only in the small circle of bureaucratic and military elites. As a result, various articulations of interests outside the bureaucracy are more likely to be responded through the process of 'clientelistic' or absorption of aspiration without the process of involving actors outside the state bureaucracy (Zuhro et.al, 2009).

The shift from centralization to decentralization had a relatively significant effect on the emergence of informal political actors taking part in determining public policy, both at the central and regional levels (Zuhro et.al, 2009). Through the regional autonomy law
No.22/1999,the political spaces spread to the local level, from village to provincial level. If during the new political order was determined by Jakarta, political actors at the local level now have an increasingly widespread opportunity in their political activities and maneuvers. Thus, decentralization accommodates another scene in the process of democratization in Indonesia. The emergence of the diversity of actors in the political and governance process is not only in the national political arena but also in the regions.

The study from UGM (2000) demonstrates that post-Suharto local politics is marked by the revival of old political entities and the emergence of informal old elites nationwide. Investigating the context of the dynamics of politics in South Bangka held on December 9th, competing three pairs of candidates, first, JustiarNoer with RizaHerdavid with Demokrat and PKS party, secondly, the pair of Rina Tarol-DjulailiRomli with PDIP, PAN and PKB parties, lastly, the couple H. Jamro with Firmansyah with NASDEM, GERINDRA, HANURA, and PBB (Kpubaselkab.go.id). Despite the existence of this party is necessary as a legal-formal process, in practice the existence of the role of local actors in politics is always fascinating to be observed.

It is induced of the research of local actors is not only seen from one factor only such as financial, but local actors have many aspects that reflect the complexity or diversity of ways of view in politics. Moreover, the involvement of local actors in direct local election is not able to be avoided. They are local potentials that are able to contribute or demonstrate their own 
method to politics at the local level. They are able to illustrate conducive of political condition in which their role is crucial in creating a participative people. They have the ability of the involvement in mobilizing mass. On the other hand, the role of local actors in the democracy party is dominant. The phenomenon is marked by the participation of local actors in the preelection campaign process. The real contribution made by local actors in South Bangka is directly involved in the campaign accompanying candidate pairs. In addition, maneuver, strategy and approach frequently done each pair of candidates to the people.

It is certainly able to develop the public awareness in determining the choice. In addition to being able to mobilize public awareness, local actors also illustrate influence and positive image of the public with the couple of candidates who will compete in the democracy party. Nevertheless, the presence of local actors does not always have a positive impact on democracy and often the actions of our political actors hinder the rate of democratization, as it is perceived to threaten their interests. These obstacles are exacerbated by our current preconditions that are not conducive to democratization. Widespread poverty and limited public access to information sources, for example, undermine their ability to articulate their interests and control power. It prompts people involved of money politics and easily mobilized for undemocratic purposes, such as opposing election results by force, expelling groups of different religions, and encouraging discriminatory policies.

Starting from the brief description, the study of how informal political actors, methods of work and character in the process of electoral in the local level of South Bangka is essential. It needs to be in response to how the central position of actors and informal networks play an important role in encouraging electoral and democratic processes or vice versa - constraining democratic values themselves with models of clientelism and patronage (Aspinal, 2016). One of the advantages of this study is the position of researchers who are in the location a month after the election and a month after the election in South Bangka. In addition, it attempts to observe critically the presence of actors in local politics and the extent to which their role in promoting democratic processes at the local level, as well as the extent to which the role of informal actors in local politics in the effort of winning the candidate.

There were three candidates who passed the administrative and verification by the General Election Commission (KPU). They have almost the same background. The first candidate was the couple of Jamro and Firmansyah supported by Nasdem, PBB, Gerindara and Hanura. Jamro is the former incumbent candidate who led South Bangka. The number two candidate was Rina Tarol and DjulailiRomli which is proposed by PDIP, PAN, and PKB. Tarol was the first female candidate in this region. In addition, she is a member of the provincial legislative of Bangka Belitung. They are supported by parties which have nine representative persons in the DPRD. The number three is JustiarNoer and RizaHerdavid. This incumbern candidate was supported by PKS and Denocrat Party.

It became fascinating with the return of former Regent of South Bangka period 20052010, JustiarNoer to the 2015 election. In addition to JustiarNoer, there was a female candidate named Rina Tarol who was a female legislator in the DPRD of Bangka Belitung. They competed with the former Regent in the 2015 election. Compared with the South Bangka election of 2010 which only followed two candidate pairs, the celebrating of democracy in the 2015 Election will be fascinating to discuss and observe. Considering for the first time in history three times of regional general election, there was a woman candidate of Rina Tarol which supported by PDI-P and PAN. These three candidates demonstrate their own characteristics in personality and leadership. They are not only familiar for the people of South Bangka, but have emotional closeness with the people of Basel.

In leading Basel for five years, JustiarNoer could indeed be regarded as the foundation of development and government bureaucracy. With a comprehensive development orientation from the village to the city and endeavoring to create an authoritative bureaucracy, his action is still remembered by the community. Despite he is not Basel leader again. However, his work has not been emotionally forgotten. He became the hope of the people to lead Basel in 2010-2015. Basel region received various bad and even embarrassing predicate from various institutions. The Supreme Audit Agency (BPK) as the state's high institution reports a disclaimer for financial governance of South Bangka 
Regency and as Red Zone by the Indonesia Governance Index. On the other hand, Rina Tarol is recognized as a member of the women's parliament who is critical in apprehending the policies of the Basel government especially criticizing the performance of incumbent Regent of Jamro. Jamro's leadership for five years did not satisfy the public.

The number of temporary voter list (DPS) of South Bangka Regency for the elections, as many as 136,544 voters consisting of 69,968 men and 66,576 women, is certainly a struggle. It is consisted of DPS of Toboali District 49.583, TukakSadai 8,065, LeparPongok 5.287, Pongok Islands 3,233, SimpangRimba 17.788, Payung 14.295, PulauBesar 7.045, and Airgegas District 31,248 voters (source: KPUD Basel). Election in Basel has ended with the triumph of the couple who get 31,538 votes or $31.3 \%$ (KPUD Basel, 2015), and defeated the incumbent candidate. From this case, the substantial concern in this research is how the unique roles, methods, networks and characteristics that informal actors play in the 2015 election in Basel.

From the data released demonstrated that DPS of Toboali almost equal to three DPS in Payung and SimpangRimbasubdistrict and PulauBesar about 39,000. However, the experience of elections South Bangka, the figure is decisive to $50-60 \%$ victory. Party machine 10 $15 \%$, campaign $10 \%$ and the rest is vision, mission and candidate program. Therefore, an irony in rational society in which the fall of choice is more dominated by factor figures rather than issues or programs (interview, Nov 31, 2015). Indeed, the issue or program that contains the need and hope of the society which is formulated by the candidate should be the dominant factor for voters in determining the choice. Because by the time it becomes a ruler, it is easy for the public to judge and justify the running of the elected candidates' government. When they have become a ruler then the society easily provide judgment and justification in running the government of the elected candidates.

\section{RESEARCH METHODOLOGY}

According to Bogdan and Taylor, qualitative research is a study that produces descriptive data in the form of written words or orally from people and behavior that can be observed (Moleng, 2011). This approach is directed to the background of the individual in a holistic way, and should not isolate individuals or organizations into variables. It is conducted in South Bangka Regency where there was a phenomenon of the involvement of informal actors in political election of 2015. This field research conduct series of interviews and shodowing technic (UGM \& ANU, 2014).

To analysis data is conducted by doing reduction, display and conclusion drawing data (Lisa, 2010). In other words, analysis process conducts since data collected. In qualitative analysis, data objectification is obtained from the meaning of the existing data. The analysis work is more on organizing the findings, and constructing the findings in the frame of the object under study. It will elucidate an objective conclusion.

\section{THEORETICAL FRAMEWORKS}

Theory is a foundation in discussing the issues to be in carefully so as not to deviate from the topic to be studied. The theory is also one of the most crucial elements of research to elucidate the social phenomenon that will be meticulously. Kerlinger said that theory is a set of concepts, definitions, propositions that present a systematic review or phenomenon that exists by demonstrating specifically the relationships among variables associated with phenomena in order to provide explanations and predictions for the phenomenon. ${ }^{1}$ To elucidate the above problems then the researchers used several theories such as:

\section{A.Elite Theory}

The word of elite can be interpreted in various contexts which mean best, special, noble or the best of others. Pereto defines that the elite is able to be simply defined as individuals who have special or more ability in certain activities such as political knowledge or business. Moreover, Pareto divides the term elite into two things. First, governing elite is a group of leaders who directly or indirectly have a role in governing society. Second, non-governing elite is as a reminder or critic of the elite group itself. In contemporary social knowledge, the word of elite refers to groups that have high status in society for everything reason. ${ }^{2}$

The elite theory defines that within each society is divided into two categories: 1) A small group of people who have the ability and therefore occupy positions to govern, and they

${ }^{1}$ Zamroni. 1992. Pengantar pengembangan teori social. Tiara Wacana, Yogyakarta, Hal2.

${ }^{2}$ Dunleavy, Patrick \& O'Leary, Brendan. 1987. Theories of the state: The politics of liberal democracy. New York: Meredith Press. 
are called: (a) the ruling elite and (b) the unelected elite. 2). A large number of masses are destined to be governed (Varma, 1975).

\section{B.Modality Theory}

In the direct electoral system as applied by Indonesia, at least three capitals are required as a prerequisite for a candidate to be elected. All three of them need each other, though it does not mean it will fail miserably if the lack of one of them. These three capitals are social capital, economic capital, and cultural capital (Harker 1995). Differences in access to these three capitals will determine the success of a person in obtaining economic, social, and political opportunities.

It is able to be utilized to elucidate the elite forces by using the availability these capitals and the absence of three Bourdieu capitals (Harker 1995).First, it is the availability of social capital. According to Putnam (2008), social capital refers to societal organizational frameworks, such as networks, norms, mutual trust that enables mutual coordination and cooperation between the two groups.

The concept that underlies social capital has existed for a long time. Philosophers who emphasize the relationship between pluralistic and democratic societies include James Madison, Alexis de Tocqueville, and many other writers in the dominant pluralist tradition in American political science. Second, it is the availability of economic capital. A person is able to have economic capital because of the results of his own business or the inheritance of his ancestor. Furthermore, these groups are conglomerates, entrepreneurs, merchants, and professional workers. In the context of elections, economic capital does not necessarily mean its own capital. A candidate is also able to deploy other people's economic capital.

In this case, where a candidate seeks support from or by businessmen and broker. Nevertheless, the risk is clear, if elected then the candidate must return the loan. These returns can be direct, which usually force them to abuse unlawful paths, such as receiving gratuities, bonuses, commissions, and tributes.

The return of loans is also able to be indirect, through the division of projects or winning the project. Third, the availability of cultural capital utilizing David Efendi (2017) define, the term symbolic capital to replace cultural capital. Cultural capital, referring to Bourdieu, is related to the level and type of education, the ability to appreciate art, cultural experience, and religion. This group is included by scholars, intellectuals, academics, humanists, artists, and religious leaders (especially those attached to celebrity image).

Cultural capital is substantial for anyone who is active in politics, because politics requires broad-minded actors and adequate intellectual capacity, especially to understand, analyze and solve problems. Decision makers will not be able to offer a good policy for the public goods without it.

Table 1: Bourdieu Modalities

\begin{tabular}{|c|c|}
\hline $\begin{array}{l}\text { Type of } \\
\text { Capital }\end{array}$ & Capital Coverage \\
\hline Social capital & $\begin{array}{l}\text { 1. Network (domestic and } \\
\text { foreign) } \\
\text { 2. Status in society (education } \\
\text { and religion) } \\
\text { 3. Descendants (royalty and } \\
\text { ruler) } \\
\text { 4. The power of influence in } \\
\text { society } \\
\text { 5. The organizers of baronial } \\
\text { and respected organizations }\end{array}$ \\
\hline $\begin{array}{l}\text { Political } \\
\text { capital }\end{array}$ & $\begin{array}{l}\text { 1. Political position } \\
\text { 2. The experience of organizing } \\
\text { the masses } \\
\text { 3. Descendants (noble and } \\
\text { ruler) } \\
\text { 4. Strength over public decision } \\
\text { making } \\
\text { 5. Reputation and legitimacy }\end{array}$ \\
\hline $\begin{array}{l}\text { Economic } \\
\text { capital }\end{array}$ & $\begin{array}{l}\text { 1. Wealth (financial and } \\
\text { material) } \\
\text { 2. Descendants (noble and } \\
\text { ruler) } \\
\text { 3. The power of influence in } \\
\text { society } \\
\text { 4. The middle class Islam } \\
\text { student } \\
\text { 5. Government bureaucrats }\end{array}$ \\
\hline $\begin{array}{l}\text { Cultural } \\
\text { capital }\end{array}$ & $\begin{array}{l}\text { 1. Education degree } \\
\text { 2. Religious image and symbol } \\
\text { 3. Appreciation of art and culture }\end{array}$ \\
\hline
\end{tabular}

Like Bourdieu, Max Weber (1919) elucidates a substantial analytical base to illustrate how certain elites gain legitimacy over the power gained. Weber provides three types of legitimacy: legitimacy derived from traditional power of family genealogy; charismatic powers acquired due to the integrity of the elite or candidate, and the last legal-rationale in which the elite gains power due to legal mechanisms such as elections. 


\section{C.Local Strongman}

The existence of the practice of informal governance or the shadow state is not something new. At the theoretical level, discussions among observers about the shadow state phenomena have appeared in 1900s. For example, Barbara Harriss-white (2003) has written about the interrelation between informal economy and shadow state practice by referring to the findings of his studies in India in the 1990s.

In the context of Indonesia, especially in the post-New Order period, it should be acknowledged that critical analysis of shadow state practices in relation to decentralization and regional autonomy policy in post-Soeharto era (Nordholt, et.al 2009). According to Harrisswhite, there are at least two notions attached to the terminology of the informal economy. First, business activities of individuals, and / or companies not registered to the government, and not paying taxes. Second, it deals with the behavior of formal institutions (both government and private) to avoid the reach of regulation. In addition, this form of informal economy called tax loose, misuse of public policy, corruption, collusion and the coercive of privatization of state assets.

From the above two categories of informal economy activity, it is evident that the first informal economy is the arena for the "little one" (farmers and small businessmen) while the second form of informal economy is dominant of the "big one" (big businessmen and state officials).

At least there are four common characteristics of the informal market and shadow state practice. First, it is obvious that the informal market and shadow state are present, growing and developing as a result of the weakening function of state institutions. Second, the accumulation of short-term political and economic benefits beyond the framework of formal regulation is the main objective of transactions through the informal market. Third, the working mechanism of the informal market and shadow state varies widely, which can generally be divided into two main categories: through manipulating public policies and through networks of individual alliances, as well as institutional alliances. Fourth, the actors involved in informal market and shadow state are state actors and societal actors.

\section{D.Actor Theory}

Structural theory illustrates the concept of an individual who is elucidated to be an actor (agency) that has a role to produce and reproduce structures in an established social order. Thus, agents are able to alter and produce new structures if they do not determine a compatible structure from existing structures.

Structural theory that focuses on repetitive social practice is basically a theory which links between agents and structures. However, it maintains that the agent's actions can be seen as repetitions. It demonstrates that the activity is not produced once and directly by social actors, but they continually re-create it in a way, and in the same way they proclaim themselves as actors. Through their activities, the agency creates conditions that enable this activity to take place. Thus, activity is not generated through consciousness or through constructiveness of a reality, nor created by social structures. Instead of expressing themselves as actors, people engage in social practice that both consciousness and structure are created.

\section{BANGKA SELATAN: POLITICAL ARENA AND INFORMAL POLITICS}

\section{A.Relation candidates-supporters}

The interaction of local actors in the arena of political competition, the actors in the society compete for the elected official. In the competition process the actor meets, comes into direct contact, and builds a network with other political actors. As a result, the arena of local elections has become an arena of interaction between local political actors in Bangka.

What's interesting about local politics in South Bangka is about how informal electoral democracies act: who does what and by relying on what capital the actor plays in his role. The election experience in South Bangka demonstrates that not only political parties are involved, but also the emergence of informal political actors such as businessmen, Islam clerics, and NGO elites.

Based on the framework of economic modality, businessmen are divided into two categories. First, tin businessmen are middle-class society people who work in the field of mining. Mining is one of the significant sectors for economic support in South Bangka Regency, therefore, most of the people who switch from farmers to tin miners. Not infrequently there are more successful with the business in the field of mining than to agriculture. It 
legitimizes a tin businessman as a person who has a lot of money at the same time. In addition, South Bangka was illustrated as one of the tin supply districts spread in the Bangka Belitung Islands Province. Second, pepper and palm businessman, among the people engaged in this field are the people who live in rural areas.

The findings of researchers in the field indicate a special relationship illustrated by informal actors. In the candidate pair number three, JustiarNoer and RizaHerdavid, there is a relationship demonstrated between businessmen and village clerics in gaining the support of the society. On the other hand, special relationships are also illustrated simultaneously between candidates with several NGOs (interview, 12/1/2015). The relationship is created intentionally conducted by the candidate with the village clerics who are believed to mobilize the masses. They have more influence than NGOs and CSOs. Furthermore, they became the central figure of public concern in some villages. In one moment, one of the candidates visited the house of one of the village clerics. Moreover, the meeting was witnessed directly by the followers of village clerics and constituent candidates. It is what will have a positive impact in determining the choice of society. The meeting was assumed that the village cleric had symbolically declared his choice of the candidate pair. It is undeniable that in some villages, they made their followers and the community as a political reference in determining the political choice.

Meanwhile, not much different from the pair number two, Rina Tarol and DjulailiRomli, there is a special relationship that is illustrated with businessmen and NGOs (interview, Nov 11,2015). In addition to relying on a relationship oriented to gain voice support, the power possessed pair number two is a party machine works. They are supported by PDI-P party. The strength of the party is evidenced by the gaining of the most positions in the legislative election about five positions. While in the presidential election, the victory of Joko Widodo and JusufKalla is not able to be separated from the hard work of PDI-P and its cadres in the party of democracy competition.

The candidate number two was not only a network with several NGOs, but also the PDI-P party's machine power is the capital in winning the couple of Rina Tarol and DjulailiRomli. It is proven by direct instructions from the PDI-P Central Executive Board. PDI-P general secretary, HastoKristyanto in a regional working meeting (Rakerda) said:
"The whole party machine in PDI-P will be mobilized for the winning of the election. Its capital is coordination, and effective campaign planning by PDIP in obtaining the voter's support. The strategy and spirit of working together of party machine, from DPP to local level, will work in one way winning our candidates so that political funding for election can be decreased" (MetroTv News.com. accessedDesember 2, 2015.

On the other hand, it is extremely different from the candidate number one of Jamro and Firmansyah. In addition to being an incumbent Regent, Jamro is known as one of the influential public figures in his era. It demonstrates the pattern of relationships played a little different from the other two candidates. Moreover, the strategy utilized by the candidate number one is more prioritizing village clerics as capital in gaining mass support (interview, Nov 11, 2015).

The role of village clerics in politics is not able to be underestimated. As an informal leader, the village clerics are people believed by the population to have enormous and charismatic authority. In several districts where the majority of villagers, they are demonstrated as a reference in determining political choice that occurred in the District of PulauBesar, Payung, SimpangRimba, and Air Gegas. The figure of village clerics is a role model in the social life of the community. All the explanations avowed by village clerics are often accepted by followers and the community. On the other hand, conducive relationships are illustrated by the couple of Jamro and Firmansyah to businessmen in South Bangka especially palm and pepper businessmen. With a businessman background, it demonstrates that Jamro and Firmansyah are easily in creating relationships with fellow businessmen to gain political support.

There is something fascinating from the network demonstrated by three candidate pairs in the South Bangka elections. Political parties illustrate a minimal role in organizing campaigns to support candidates. However, it does not mean that political parties are not involved in the process of voice mobilization. The candidate who serves as the main body of a political party is able to dominate the party and effectively can make stewardship at the branch level of the party to become his personal team. But, in a highly competitive electoral system, a candidate will usually rely on several local officials, leaders and party cadres. They become the winning team of the candidates. Therefore, the winning team of a candidate who derives from party officials is filled by political party cadres. PAN 
demonstrate an organized and systematic political party by carrying the chairman of DPD PAN District DjulailiRomli as Vice Regent paired with Rina Tarol. It illustrates the winning team of pair number two was a person who are the cadre of PAN.

\section{B.Two Legs Politics}

In the process of democracy, it has become commonplace when local actors and nongovernmental organizations (NGOs) spontaneously express their attitude to support one of the candidates who will compete for the executive position. It is not able to be denied such a thing happens almost in all regions of Indonesia. In South Bangka, businessmen spontaneously have good faith to support one of the candidates. However, before deciding to support one of the candidates, they are analyzing with reference from various surveys conducted by several research institutes in Bangka Belitung (interview, Oct 2, 2015). For businessmen whose business is not dependent on the government, election is no more than limited momentum to channel their political rights and obligations. However, for businessmen whose business is dependent on the government, election is a momentum to secure the sustainability of their businesses by offering various assistances to candidates. In addition, the businessman's motive is economic profit. The two-leg, three-leg, and fourleg political strategies are the usual thing that many businessmen have been done.

In the context of political dynamics in South Bangka, the dominant businessmen to play are tin businessmen in mining. The support provided by tin businessmen to all candidates has an orientation in securing their owned of mining business. As a consequence, selected candidates will provide convenience to such businessmen such as granting mining business permits (IUP). Since 2005, the local government of South Bangka Regency has issued 99 mining business licenses issued by South Bangka Regency government to private companies (koranbabel.com, Nov 24, 2015).

This behavior is well defined as 'clientelism' as a political relationship based on the exchange of material profits (money / things / economic opportunities) with political support. Furthermore, it arisen to the CSOs and NGOs. However, the orientation between NGO and businessman is slightly different. NGOs have high hopes for selected candidates to support their programs (interview, Nov 14, 2015). Businessmen and NGO leaders employ mostly two-legs politics (PolitikDua Kaki). The findings of researchers in the field, there are at least two businessmen who utilize two-legs politics. It demonstrates that the support of businessmen is not only focused on one candidate, but also with other candidates (interview, sept 5, 2015). Moreover, it is conducted by NGO leaders, one of the NGOs who concern with youth affairs employ two-legged politics by promising a number of votes with each candidate. The strategy conducted by Non-Governmental Organizations, claiming the number of members in the structure around 150 people. In addition, the half of the members will support to one of the candidates, and the other half will vote to the other candidate (interview, Nov 15, 2015). It is not absorbed by all candidates.

\section{INFORMAL ACTORS AND NEW LOCAL POLITICS}

Political circumstances in various districts within the region of South Bangka regency are increasing. The more massive maneuvers and strategies performed by candidates and winning teams. Furthermore, the actors of local actors who have influence in society contribute to enliven the dynamics of politics before the election's day. The involvement of local actors in the direct Regional Head Election is not able to be avoided. They are local potentials that can contribute on politics at the local level. They are able to create a conducive political condition, where their role is crucial in creating a participatory people. Moreover, they have the ability of mass mobilization. On the other hand, the role of local actors in the election is dominant. The phenomenon is marked by the participation of local actors in the pre-election campaign process. In addition, the real contribution conducted by actors at the local level is directly involved in the campaign accompanying candidate pairs. It is certainly able to mobilize public awareness in determining the choice. In addition to being able to mobilize public awareness, local actors are able to influence the society to vote one candidate.

\section{A. Local Bussinesmans}

It is not unusual that the business world has a close relationship with politics. An election becomes an arena of it. It is manifested in the form of policies that create comfort and security in investment and business. The simultaneous election in four regencies in Bangka Belitung, will be an arena to compete for the interests of several groups. Not only the candidates who competed in the area concerned, but also political actors and other economic actors, such as entrepreneurs. The involvement of businessmen in the election is not able to be avoided. With the economic modality, they become one of the actors who have influence in winning one of the candidates. In addition, there is a positive synergy between candidates who will 
compete in the election with local businessmen. There is the hope of a relationship that gains the support with as much as possible. At least there are several roles undertaken by entrepreneurs in the election. First, as donors, they become donors of one candidate because of economic modality. Second, the involvement in accompanying candidate in campaigning, the researcher findings, on several occasions, discovered the figure of the businessman accompanied the campaign of candidate.

In Tiram Village, TukakSadai district, Edi Junaidi or who is usually called Yong. He is encountered sitting directly adjacent to the candidate number three, namely JustiarNoer. Third, disseminating the vision, mission and the candidate program it supports. Not only as a donor of funds, but also the role of businessmen in South Bangka is as a campaigner. Fourth, in addition to being directly involved in the campaign process, a prominent role organized to businessmen for the candidate is to facilitate various meetings between candidates with the society. furthermore, the businessmen provide several buildings and homes to be used as secretariat of winning and candidate residence (interview, Nov 18.2015).

Existence of Tauke is not able to be separated from the modalities in his possession. In Basel, especially in Toboali as the District's Capital, he is a distinctive term for a businessman and a political figure. He is elucidated as the leader of worker. $\mathrm{He}$ is synonymous with treasure or as someone who has and owns many treasures. While Rusmin explains:

"Tauke is a Chinese language that also means boss. Its term is employed among Chinese businessmen, now known as Toke. The term Tauke to the politics of Bangka is not able to be separated from its alignment to all the people and groups in South Bangka area regardless of tribe, religion, race and class, including political affiliation.Generosity indeed illustrates its local political elite as a symbol of the prosperity. Not surprisingly, he has always been a consultation place in the face of problems. As if when met with him, all the problems are resolved. At least the obstacle was awkward. He then aligned with the Jawara in Banten and Blater in Madura.On the other hand, as local political elite, he has loyal followers. Their loyalty to him is not just about political affiliation, but his generous attitude that makes there a close relationship between them" (interview, October 31)

\section{B. Village Clerics (Kyai Kampoeng)}

In the local-historical trajectory, village clerics hold important positions in the life of society. They become a status with significant authority and sometimes this position is more obeyed by society than to their leader. Therefore, the position of village clerics is more respected than the elites who dedicated in the government bureaucracy. This strategic position that illustrates the village clerics as highlight in the community, almost all of which are delivered by them, believed by the community.

Ahead of the 2015 General Election in South Bangka, many ways were done by each candidate. In addition to using an organized team based on territory, candidates take advantage of the influential village clerics as ballots. By utilizing these actors, candidates desire they can encourage their followers to support the candidate. In other words, they take advantage of the social trusts in a network to gain political support. Even the candidates recruited village clerics in the structure of the winning team.

From the findings, there are at least three reasons why the village cleric supports one of the candidates. Firstly, the reason for the candidate figure to be the determinant in deciding his support. They are emotionally aware of the candidates because they are from the same village. In addition, they observe the candidate's ability factor. Secondly, they observe the formulation of programs designed by more pro-village candidates (Interview, Oct 7/2015). Thirdly, the establishment of disclaimer for financial governance of the Regional Government of South Bangka Regency by BPK and the Red Zone in the award of IGI for the management of the government causes a strong reason for the village clerics to support the candidate. The symbolic modalities possessed by candidates with the level of master degree, they assume that the candidate they support is able to overcome it all (Harker, et.al, 1990).

The most prominent form of contribution conducted by village clerics in supporting candidates is to participate in accompanying candidates to campaign in areas where village clerics are domiciled. In addition, they facilitate meetings between the community and candidate 
(interview, Nov 13, 2015. Based on the structural theoretical framework introduced by Anthony Gidden, the village cleric is an agent, as an intermediary that connects candidates with voters. The role of the village clerics has only power in a limited environment. In other words, they only have an influence on the area where they live. The power of that influence was obtained to his contribution as a speaker, and took care of the body while one of the villagers died. As a preacher is more in the hearing by the community. Therefore, his political decisions are also followed by his followers. In addition, taking care of the corpse is a valuable role of a village cleric and have a positive impact of the community. It demonstrates the village cleric has an influence in the political field. However, the power of this influence occurs only in the village where the village cleric is domiciled, while in the other villages, he is only known as a preacher and has no significant influence in the other villagers. The role model of this village cleric is a model of political involvement that is commonly practiced in various villages in South Bangka.

\section{NGOS elites}

One of the phenomena in the reform era is the growth of various NGOs in various social activities, nation, and state. The presence of NGOs can be an alternative in conveying the aspirations of communities that have not been accommodated by representative institutions or political parties. In fact, it can be a channel of community aspirations to be conveyed to the executive branch, oversee the running of the state. In the implementation of elections, NGOs are able to participate in improving the oversight of the elections since the formation of law on the role of political parties, KPU, and election. It is ideal if all is organized in strengthening democracy. They are expected to be more referring to values, long-term for the good of the whole nation.

According to Efendi (2017 \& 2010), civil society always can take and positive advantage to the process of electoral for political education. For instance, as community leaders, they become main targets for candidates to create the election winning team. There are NGOs that hold political commitments with the candidates. However, there are also NGOs that are opportunistic and shorttermed, seeking for more rent. Election is the momentum to get out of their routine for a while. NGOs tend to partisan gaining benefits through election such as by becoming a winning team. In South Bangka, almost all NGOs are involved in supporting one of the candidates (interview, Oct, 4, 2015). Not many NGOs are able to maintain their independence and integrity in the 2015 Election.
The findings of the researchers of the real contributions conducted by NGOs are to campaign candidates to general voters. The role of NGOs in South Bangka election is quite prominent especially in socializing the candidates that supported. As an institution that has a lot of time mobilization in almost every district in South Bangka, NGOs, either directly or indirectly, have become tools of KPU assistants in introducing directly who will compete to the election. In addition, the involvement of NGO leaders in accompanying campaigning candidates is dominant. It is evidenced in some campaign momentum such as in Toboali, there is an involvement of NGO leaders, even one of them being a campaigner team.

\section{CONCLUSION}

The shift from centralization to decentralization has had a relatively significant impact on local political developments. One of them is the emergence of local actors who participate the dynamics of politics in Indonesia. In the context of local politics in South Bangka, informal actors is well known as Taukecharismatic figur. But they are not the onlyone. Almost all community especially in the capital regency is familiar of the Tauke. On the other hand, it is illustrated for having a lot of masses mobilization. It is evidenced by the presence of loyal followers. It can be concluded that the network relationships demonstrated by each candidate with the political actors at the local level provide a substantial role in the success of gaining mass support in the Election of South Bangka. The presence of political actors at the local level illustrates the dynamics of politics prior to election. In addition, the support of political support provided by local actors is also varied. The businessmen are putting forward the economic modalities such as finance. While NGOs has its own way by mobilizing constituents to gain support for the candidate supported. Moreover, village clerics relied more on symbolic modalities as the power of influence of constituents. The form of contribution illustrated by village clerics to candidates is to become connectors between the voters and the candidates. In addition, the closeness of personal and emotional relationships, but also employed as a way to discuss and articulate to the aspirations of constituents. Thus, the success of candidates in the election is strongly influenced by informal political activities and the role of informal 


\section{ACKNOWLEDGMENT}

We owe to many people for finishing this project especially for our informants in Bangka that I cannot mention one by one here. Special thanks to the Department of Governmental studies, UniversitasMuhammadiyah and to our supervisor, BambangEkaCahaya. Also, our colleagues in Rumah Baca Komunitas that provide priceless feedback and productive discussion during this research project began in early 2015.

\section{REFERENCES}

Dunleavy, Patrick \& O'Leary, Brendan. 1987. Theories of the state: The politics of liberal democracy. New York: Meredith Press.

Efendi, David \&Kurniawan, N Indra. 2010. Politik elite Muhammadiyah: studi tentang fragmentasi elite Muhammadiyah dalam pemilihan umum presiden tahun 2009). Thesis di Universitas Gadjah Mada Yogyakarta.

Efendi, David. 2017. Muhammadiyah danPiplres: Wahana Civil Society dalam mengupayakan pendidikan demokrasi. Yogyakarta: Simpang

Fisipol UGM, 2000, "Kecamatans ebagai basis Pengembangan demokrasi, pelayanan publik, Intermediary dan ekonomi di tujuh Provinsi", Laporan tidak di publikasikan.

Firmanzah.2010. Persaingan, legitimasi kekuasaan, dan marketing politik. Jakarta: Gramedia

Gunawan, Imam. 2013. "Metode Penelitian Kualitatif Teori dan Praktik". Yogakarta: Bumi Aksara.

Lisa, Ridvia. 2010. Analisis Data Kualitatif Model Miles Dan Huberman. Padang. Universitas Negeri Padang
Moleong, Lexy J. 2011. Metodologi Penelitian Kualitatif (edisirevisi). Bandung

Pramono, Agus. 2005. Elite Politik: yang loyo, dan harapan masa depan, Jakarta

Rahmawati, Dian Eka. 2011. Diktat Mata Kuliah Metode Penelitian Sosial. Yogyakarta. Universitas Muhammadiyah Yogyakarta

Richard Harker, dkk (ed.). 1990, dalam judul buku pengantar paling komprehensif kepada pemikiran Pierro Bourdieu, (Habitus x modal $)+$ ranah $=$ praktik, Terj. Yogyakarta: jalan sutra,

Singarimbun Masri, 1992.Metode penelitian survey, Jakarta LP3S

Simanjuntak, Bungaran Antonius \&Sosrodiharjo, S. 2014. Metode Penelitian Sosial (edisiRevisi). Jakarta: BukuObor.

Schulte. Henk, et.al (ed). 2009. Politik Lokal di Indonesia. Jakarta: BukuObor.

ANU \& UGM. 2014. Panduan Penelitian Lapangan Pemilu Legislatif 2014.

Varma, SP. 1975, Teori Politik Modern, Jakarta: Raja Grafindo Persada,

Zuhro, Siti, dkk.2009. Demokrasi lokal, peranan aktor dalam demokratisasi. Yogyakarata: Penerbit Ombak

Zamroni. 1992. Pengantar pengembangan Teori Social. Yogyakarta: Tiara Wacana

Aspinall. Sukmajati, 2015, Politik Uang di Indonesia: Patronase dan Klientelisme pada Pemilu Legislatif 2014. Yogyakarta: Penerbit Polgov.

Zed, Mustika. 2017. Metode Penelitian Kepustakaan. Jakarta: Buku Obor. 